\title{
Role of TGF $\beta$ and myofibroblasts in supporting the propagation of human embryonic stem cells in vitro
}

\author{
NEERAJ KUMAR, PRASAD PETHE and DEEPA BHARTIYA* \\ Stem Cell Biology Department, National Institute for Research in Reproductive Health, Parel, Mumbai, India
}

\begin{abstract}
The feeder layer constitutes a prerequisite for the undifferentiated proliferation of human embryonic stem (hES) cells in vitro. However, a few feeders have been reported to be nonsupportive in nature, suggesting that these feeders exhibit a different transcriptome and proteome, in comparison to their supportive counterparts. In an attempt to identify factors required for undifferentiated growth and many downstream applications of hES cells, transcriptomes of supportive (mouse fibroblasts derived from 13.5dpc embryos and human fetal fibroblasts) and non-supportive (mouse fibroblasts derived from 18.5dpc embryos) feeders were analyzed. Furthermore, the parallel correlation of data generated in the microarray study with the published proteome data of supportive feeder fibroblasts, helped us to focus on the proteins which seem to be likely candidates in supporting the undifferentiated expansion of ES cells in vitro. Our results indicated that TGF $\beta$ and its associated signaling molecules facilitate the undifferentiated proliferation of hES cells in vitro. The transient differentiation of feeder fibroblasts into myofibroblasts may be the decisive factor for a feeder layer to be supportive or non-supportive in nature. We propose that the microenvironment of feeder myofibroblasts dictates TGF $\beta$ to support proliferation and apparently plays the contradictory role of facilitating differentiation when feeder support is withdrawn, possibly by acting through different signaling mechanisms.
\end{abstract}

KEY WORDS: embryonic stem cell, feeder layer, microarray, TGF $\beta$, myofibroblast

In order to realize full clinical potential of human embryonic stem (hES) cells, a major challenge lies in its large scale production for transplantation which is restricted by the use of feeder layer. Mouse embryonic fibroblasts (MEF), although considered the ideal feeder for supporting hES cell growth, carry a potential risk of transferring animal pathogens to the hES cells and thus making them unsuitable for clinical use. Moreover, release of nonhuman sialic acid Neu5Gc from MEF make hES cells more immunogenic and thus possible rejection at the time of transplantation (Martin et al. 2005). Human feeders from various sources have also been used for hES cells derivation and culture e.g. fibroblasts obtained from fetal muscle, skin, lung of which fetal lung fibroblasts were reported to be non- supportive (Richards et al. 2003). Thus it becomes pertinent to identify the proteins/ factors that are highly expressed/produced by feeder fibroblasts that facilitate undifferentiated proliferation, expansion and maintenance of pluripotency of embryonic stem cells in vitro, with the hope to further refine feeder free culture protocols in future.

Studies are available in literature which aimed to identify the secretory factors in the conditioned medium using tools like 2-DE
MALDI TOF/ TOF (Lim et al. 2002) and 2D LC MS/MS (Prowse et al. 2005, 2007). The main problem encountered in these studies was the presence of albumin and other bovine serum proteins that mask the separation of other low abundant and interesting proteins on 2-DE gels. In order to overcome this problem, cells were serum deprived for $16 \mathrm{hrs}$ prior to analysis but this has been invariably associated with the expression of several stress- related proteins (Lim et al. 2002). Non- optimal serum deprivation induces stress resulting in cell lysis and several intracellular proteins were identified during proteome analysis e.g. metabolic enzymes, heat shock proteins and nucleus-associated proteins.

\footnotetext{
Abbreviations used in this paper, $\alpha$-SMA, alpha smooth muscle actin; BMP, bone morphogenic protein;dpc, days post coitum; ECM, extra cellular matrix; FGF 2, fibroblast growth factor-2; hES, human embryonic stem; HFF, human fetal fibroblasts; MEF, mouse embryonic fibroblasts; SPARC, secretory protein acidic and rich in cysteine; TGF $\beta$, Tumor growth factor beta; GAPDH, Glyceraldehyde 3-phosphate dehydrogenase; EDTA, Ethylene diamintetra acetic acid; PVDF, Polyvinylidene fluoride; NFDM, Non fat dried milk; TBST, Tris-buffered saline.
}

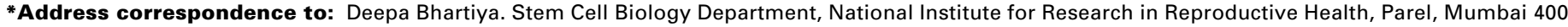
012, India. Fax:.+91-222-412-3492. e-mail: deepa.bhartiya@yahoo.in
} 
The presence of extracellular proteases was also suspected to cause lysis of certain membrane bound proteins. However, it is well accepted that proteins belonging to the category of extracellular matrix proteins, cell cytoskeleton and growth factors are most likely involved in the maintenance of hES cells growth since they are associated with variety of events including cell adhesion, cell proliferation, differentiation etc. (Lim et al. 2002; Prowse et al. 2005, 2007; Kueh et al. 2006; Eiselleova et al. 2008).

An earlier report from our laboratory has shown that feeder layers derived from $13.5 \mathrm{dpc}$ CF-1 mouse embryo and human fetal fibroblasts (HFF) are supportive for hES cells culture (Kumar et al. 2009) whereas the feeder layers derived from 18.5dpc mouse embryo exhibit massive differentiation in hES colonies beyond 12 passages. Thus in an effort to identify potential candidates having role in self renewal of hES cells, we studied the transcriptome of supportive and non-supportive feeder fibroblasts by microarray analysis and correlated with earlier reported proteomics data of factors detected in the conditioned medium of supportive feeders.

\section{Results}

\section{Feeder layers}

The hES cell colonies appear round in shape on 13.5dpc MEF feeder whereas on the human feeder layers they assume bananalike appearance (Fig 1 A,C,D,F). They could be easily passaged in an undifferentiated state on both MEF and HFF. When hES cells were cultured on 18.5dpc MEF, colonies underwent massive differentiation within 1- 2 passages (Fig1 B,E).

\section{Microarray analysis}

A total of 739 genes were found to be differentially expressed between $13.5 \mathrm{dpc}$ and $18.5 \mathrm{dpc}$ MEF of which 416 were upregulated in $13.5 \mathrm{dpc}$ MEF and 323 genes in $18.5 \mathrm{dpc}$ MEF.
Differential expression of genes equal to or greater than 1.5 fold ( $\log 2)$ was considered biologically significant for functional analysis. Such up-regulated 147 genes and 43 genes in 13.5dpc MEF and $18.5 \mathrm{dpc}$ MEF respectively were annotated at high stringency setting $(P<0.01)$ provided in the Biointerpreter tool. The genes were clustered into pathway analysis, functional categories, cellular and chromosomal localization etc. Interestingly none of the cellular pathways were found to be significantly activated in $18.5 \mathrm{dpc}$ MEF group nor were we able to classify these genes based on their cellular localization. Whereas in the 13.5dpc MEF, several pathways were significantly up-regulated and also the genes could be classified based on their cellular localization (Table 1). Further stringent filtering $(p<0.05)$ of the categories based on cellular localization yielded the following list of pathways that were activated (Table 2). These genes were involved in various functions including cell adhesion, differentiation, proliferation, ECM remodeling, growth factor and regulation etc. Table 3 gives the details of the genes that belong to extra- cellular, secretory or cell surface associated categories.

The human transcriptome was studied based on the hybridization intensity. A total of 8111 genes showed hybridization intensity greater than 100 of which 2317 genes were highly expressed and showed intensity greater than 1000 .

\section{Comparative studies of microarray data with published proteomics data}

Comparisons were based on fold changes in the corresponding eighty- five genes between 13.5dpc MEF and 18.5dpc MEF. Array hybridization intensities of HFF have been listed in Table 4. Upon comparisons, four expression patterns were observed: (i) certain genes were upregulated in both 13.5dpc MEF and HFF; (ii) certain genes were down regulated in both; (iii) upregulated in 13.5dpc MEF but not in HFF and (iv) some which were not upregulated in 13.5dpc MEF but were highly expressed in HFF. a
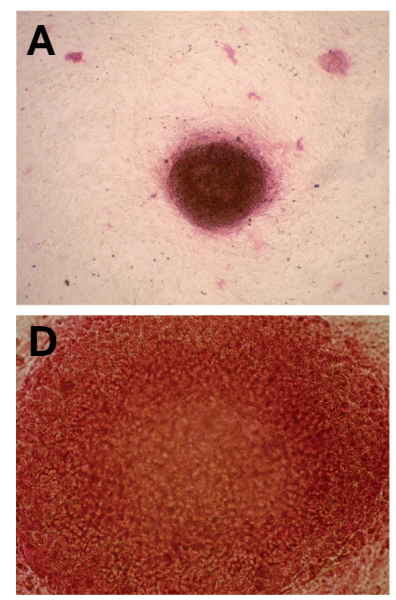
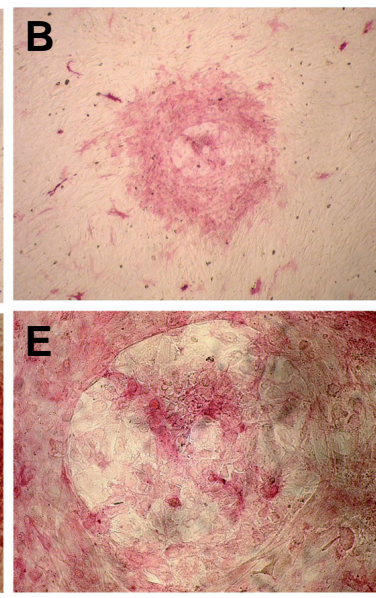
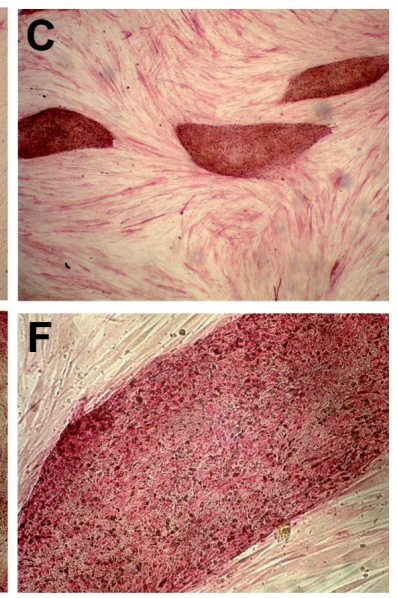

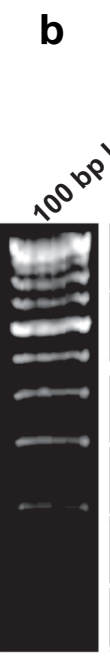

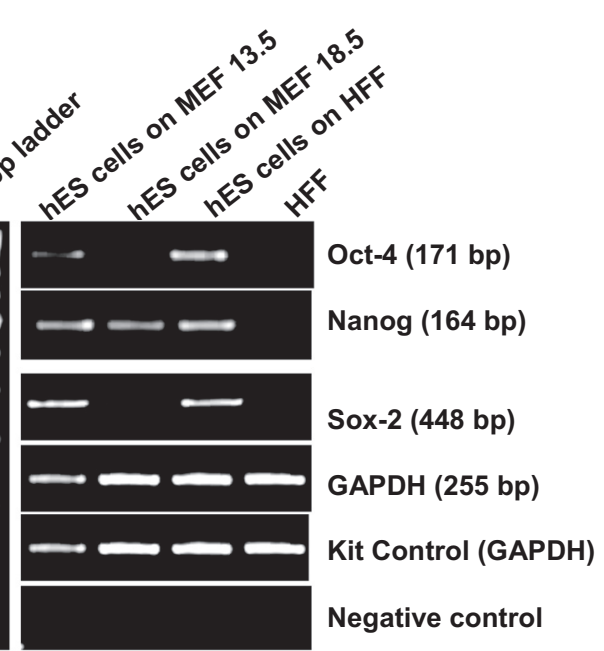

Fig. 1. Pluripotency assessment of hES cells grown on different feeder layers by alkaline phosphatase staining and RT-PCR. (a) Alkaline phosphatase (AP) activity in hES cells growing on 13.5dpc MEF (A,D), 18.5dpc MEF (B,E) and on human feeders (C,F). Note the marked absence of AP staining in the hES cells growing on $18.5 \mathrm{dpc}$ MEF (B,E). The central part of the hES colony is differentiated and lacks AP positive cells. hES colonies growing on 13.5dpc MEF and HFF reveal positive staining for AP indicating absence of any sign of differentiation. Interestingly the human fetal fibroblasts (HFF) also reveal moderate AP activity (original magnification: A- C x40; D-F x100). (b) RT-PCR analysis of pluripotent marker expression in hES cells grown on various feeders and HFFs. Note the reduced expression of Oct-4, Nanog and Sox-2 in hES cell colonies grown on MEF 18.5 indicative of differentiation. 

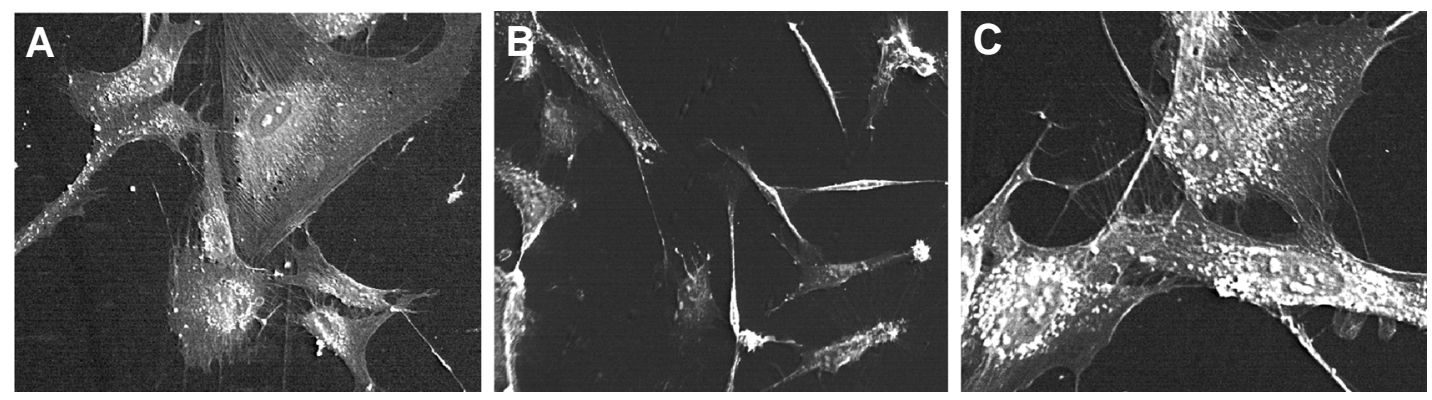

Fig. 2. Scanning electron micrographs of the feeder fibroblasts. (A) $13.5 d p c M E F$, (B) 18.5dpc MEF and (C) HFF (original magnification $x$ 500). Note the polygonal shaped myofibroblasts and the fibrils around the cell surface.
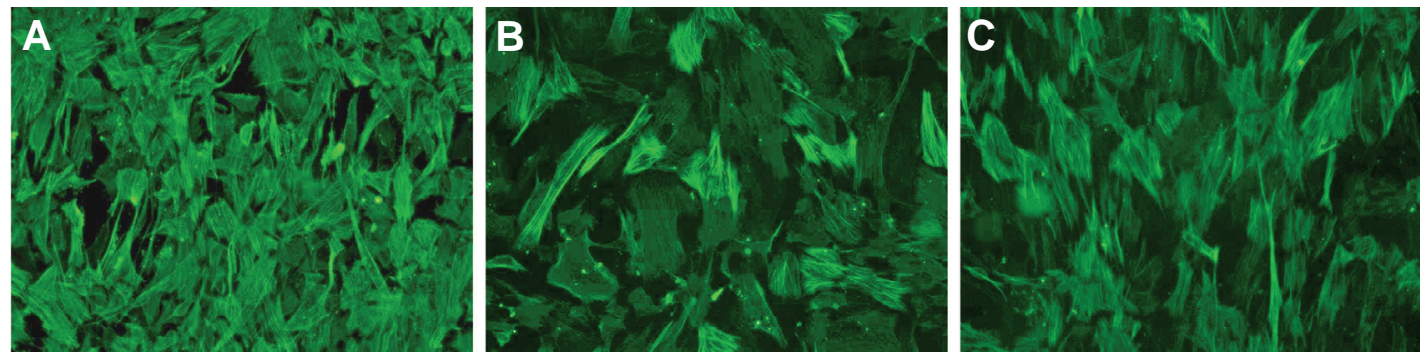

Fig. 3. Immunolocalization of - -SMA in (A) $13.5 d p c$ MEF, (B) 18.5dpc MEF and (C) HFF (original magnification $\times 100)$.

We worked on the premise that genes having a role in supporting hES cells proliferation in vitro should be upregulated in the supportive feeders. The proteins which were upregulated in both 13.5dpc MEF and HFF emerge as important candidates for further analysis and are indicated in bold (Table 4).

\section{Scanning electron microscopy}

Fibroblasts from 13.5dpc MEF and HFF appeared bigger in size, polyhedral and had several fibrils on their periphery which may be analogous to stress fibers described earlier (Tomasek et al., 2002). The 18.5dpc MEF appeared more spindle shaped, quiescent and few polyhedral cells were observed but found to be devoid of peripheral fibrils (Fig 2).

\section{Immunocytochemical localization of $\alpha$-SMA}

$\alpha$-SMA, a marker for myofibroblasts, was predominantly localized in large amounts in 13.5dpc MEF and HFF, as compared to the 18.5dpc MEF (Fig 3). As evident, the cells positive for $\alpha$-SMA were polyhedral in shape and had bundles of fibrils staining positive.

A

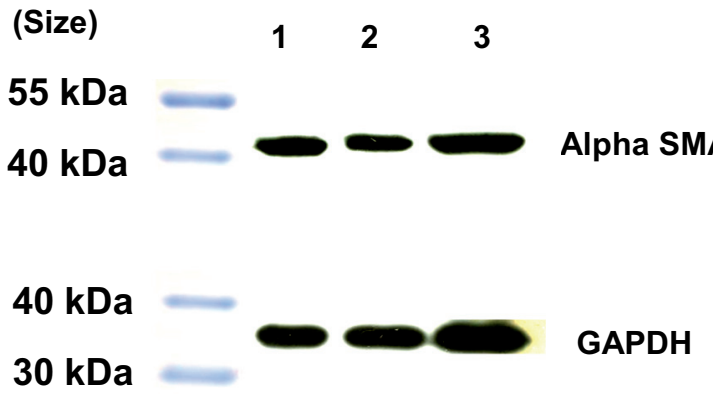

\section{Western blot analysis of $\alpha$-SMA expression}

Western blot and densitometry analysis showed the significant decrease in expression of $\alpha$-SMA in non-supportive $18.5 \mathrm{dpc}$ MEF (Fig 4 A,B) as compared to 13.5dpc MEF. Human fibroblasts $\alpha$ SMA expression, however, could not be normalized against GAPDH due to species variation as GAPDH is over expressed in HFF. However, the integrated optical density (IOD) of $\alpha$-SMA for HFF was found to be the 1.30 and 1.04 fold higher than $18.5 \mathrm{dpc}$ MEF and 13.5dpc MEF respectively.

\section{Discussion}

A comparison of one biological system versus another is an interesting approach to study their differential functional status and biological properties since this will be reflected in their altered gene expression resulting in altered transcriptome and proteome. This approach was adopted in the present study with the hope to identify certain growth factors / proteins, secreted by the supporting feeder layers that may play a role in sustaining the undifferentiated proliferation of human embryonic stem cells in vitro and

B

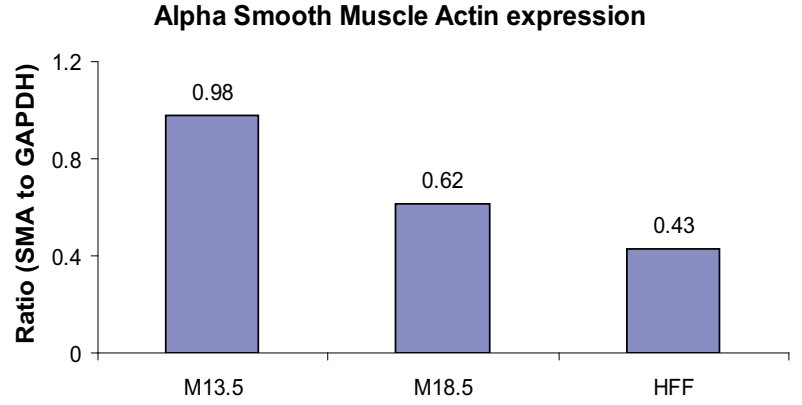

Fig. 4. Comparison of $\boldsymbol{\alpha}$ SMA protein levels among different feeder fibroblasts. (A) Western blot analysis of $\alpha$-SMA expression in feeder fibroblasts: (1) 13.5dpc MEF, (2) 18.5dpc MEFand (3) HFF. (B) Quantitative analysis of $\alpha$-SMA expression in feeder fibroblasts. Ratio= IOD alpha SMA/ IOD GAPDH; IOD, Integrated Optical Density. 
TABLE 1

\section{CLUSTERING OF GENES UPREGULATED IN 13.5DPC VS. 18.5DPC MOUSE EMBRYONIC FIBROBLASTS}

\begin{tabular}{|c|c|c|}
\hline Clusters & No. of genes & $P$ value \\
\hline \multicolumn{3}{|l|}{ Pathway } \\
\hline Glycan structures biosynthesis 1 & 4 & $1 \mathrm{E}-09$ \\
\hline Cell Communication & 6 & 0.0001 \\
\hline Apoptosis & 2 & 0.0001 \\
\hline Cytokine-cytokine receptor interaction & 8 & 0.0002 \\
\hline \multicolumn{3}{|l|}{ Chromosome } \\
\hline 14 & 13 & 0.0018 \\
\hline 1 & 16 & 0.0033 \\
\hline \multicolumn{3}{|l|}{ Biological Functions } \\
\hline Activation & 77 & $1 \mathrm{E}-09$ \\
\hline Ageing & 14 & $1 \mathrm{E}-09$ \\
\hline Angiogenesis & 35 & $1 \mathrm{E}-09$ \\
\hline Antigen Processing and Presentation & 39 & $1 \mathrm{E}-09$ \\
\hline Apoptosis & 50 & $1 \mathrm{E}-09$ \\
\hline Cell Adhesion & 54 & $1 \mathrm{E}-09$ \\
\hline Cell Differentiation & 48 & $1 \mathrm{E}-09$ \\
\hline Cell Division & 32 & $1 \mathrm{E}-09$ \\
\hline Cell Migration & 26 & $1 \mathrm{E}-09$ \\
\hline Cell Morphogenesis & 31 & $1 \mathrm{E}-09$ \\
\hline Cell Proliferation & 53 & $1 \mathrm{E}-09$ \\
\hline Chemotaxis & 18 & $1 \mathrm{E}-09$ \\
\hline Drug Response & 19 & $1 \mathrm{E}-09$ \\
\hline Endocytosis & 14 & $1 \mathrm{E}-09$ \\
\hline Extracellular Matrix Remodeling & 35 & $1 \mathrm{E}-09$ \\
\hline Gene Regulation & 37 & $1 \mathrm{E}-09$ \\
\hline Growth Factors And Regulators & 68 & $1 \mathrm{E}-09$ \\
\hline Immune Response & 82 & $1 \mathrm{E}-09$ \\
\hline Infection & 29 & $1 \mathrm{E}-09$ \\
\hline Inflammation & 68 & $1 \mathrm{E}-09$ \\
\hline Negative Gene Regulation & 27 & $1 \mathrm{E}-09$ \\
\hline Biosynthesis & 23 & 0.0001 \\
\hline Degeneration & 13 & 0.0002 \\
\hline Hemostasis & 5 & 0.0007 \\
\hline Complement Activation & 4 & 0.001 \\
\hline Anti-Apoptosis & 6 & 0.0015 \\
\hline Metabolism & 41 & 0.0025 \\
\hline Cell Cycle & 24 & 0.0045 \\
\hline Homeostasis & 15 & 0.0051 \\
\hline \multicolumn{3}{|l|}{ Cellular Localization } \\
\hline Extracellular & 62 & $1 \mathrm{E}-09$ \\
\hline Secreted & 33 & $1 \mathrm{E}-09$ \\
\hline Plasma Membrane & 32 & 0.0038 \\
\hline
\end{tabular}

may also facilitate feeder- free expansion of hES cells in future. The analysis was based on the hypothesis that any protein/ growth factor upregulated ( $>1.5$ fold, log2) in supportive $13.5 \mathrm{dpc}$ MEF and HFF versus non-supportive 18.5dpc MEF feeders may play a crucial role in self- renewal of hES cells. It is also possible that MEF and HFF may act through different mechanisms but this possibility seems to be less likely.

Several pathways involved in cell proliferation, cell communication, cytokine- cytokine receptor interaction were found to be activated in 13.5dpc MEF transcriptome (Table 1-3) and interestingly while filtering these pathways based on cell localization in both extracellular and secreted milieu, TGF $\beta$ and associated signaling molecules emerged as strong candidates (Table 4). Several TGF $\beta$ and FGF2 associated proteins have been reported earlier in the conditioned medium (Prowse et al. 2007; Kueh et al. 2006) using proteomics approach. However, the absence of the
TABLE 2

\section{SIGNIFICANT PATHWAYS IDENTIFIED FROM GENES LISTED IN CELLULAR LOCALIZATION CLUSTER (TABLE 1)}

\begin{tabular}{lll} 
Functional Pathway & No. of genes & P value \\
\hline Extra-cellular & & \\
Cell Communication & 4 & $1 \mathrm{E}-09$ \\
Cytokine-cytokine receptor interaction pathway & 7 & $1 \mathrm{E}-09$ \\
MAPK signaling pathway & 4 & 0.0044 \\
Hematopoietic cell lineage & 4 & 0.0082 \\
Small cell lung cancer & 4 & 0.0128 \\
Complement and coagulation cascades & 3 & 0.0486 \\
TGF-beta signaling pathway & 3 & 0.0486 \\
Secretory & & \\
Cytokine- cytokine- receptor interaction pathway & 7 & IE- 09 \\
MAPK pathway & 4 & IE- 09 \\
TGF beta signaling pathway & 3 & 0.0001 \\
Plasma Membrane & & \\
Hematopoietic cell lineage & 4 & $1 \mathrm{E}-09$ \\
Neuroactive ligand-receptor interaction & 2 & 0.0014 \\
Focal adhesion & 3 & 0.0028 \\
Propanoate metabolism & 1 & 0.0128 \\
Cell Communication & 3 & 0.0374 \\
B cell receptor signaling pathway & 2 & 0.0474 \\
\hline
\end{tabular}

peptide itself was attributed to the instrument limitation, protein abundance and size (Prowse et al. 2007). Results of the present study have led to the short listing of 37 out of reported 85 proteins (detected in high amounts in conditioned medium by proteomics approach) that may be involved in self- renewal of hES cells (Table 4). Interestingly, absence of activation of any well- defined cellular pathway involved in cell proliferation etc amongst the 43 genes that were $1.5(\log 2)$ fold higher $(p<0.01)$ in the $18.5 \mathrm{dpc}$ MEF (data not shown) perhaps explains why these feeder layers are non- supportive in nature and researchers prefer to use $13.5 \mathrm{dpc}$ embryos to derive feeder layers for hES cells cultures.

At the transcriptome level, an unambiguous up- regulation of TGF $\beta$ and associated molecules in $13.5 \mathrm{dpc}$ versus $18.5 \mathrm{dpc}$ MEF was evident, in agreement with published literature where TGF $\beta$ family has been implicated in hES cells proliferation (Diecke et al. 2008; Greber et al. 2007; Roberts et al., 2005). The intracellular machinery of the supporting feeder layers appears to be geared up to stimulate the production of TGF $\beta$ and associated molecules (Table 4). Latent transforming growth factor binding protein (LTBP 1) was found to be differentially upregulated in supportive feeders. It is an extracellular matrix glycoprotein and plays a critical role in controlling and directing the activity of TGF $\beta$ by binding to latent TGF $\beta$ and thus regulating its availability and activity (Prowse et al. 2007). The three components of extra cellular matrix identified viz fibronectin, SPARC and thrombosondin have all been implicated in stimulating the production of TGF $\beta$ directly or through LTBP 1. Fibronectin is an extracellular matrix protein which has been implicated in the TGF $\beta$ signaling via assembly of LTBP1. SPARC is a glycoprotein that is also understood to modulate the action of growth factors including TGF $\beta$. Thrombospondin is also known to activate TGF $\beta$.

Regulation of $\mathrm{hES}$ cells self- renewal is a complex mechanism. Three key pathways implicated in $\mathrm{hES}$ cells differentiation, pluripotency and growth are Wnt, Inhibin and BMP/ TGF $\beta$ (Prowse et al. 2007). However, Wnt/ beta catenin activation does not appear to be important to maintain undifferentiated and pluripotent state 
TABLE 3

\section{CANDIDATE UPREGULATED GENES IN 13.5DPC MEF GROUPED ACCORDING TO CELLULAR LOCALIZATION}

\begin{tabular}{|c|c|c|}
\hline Unigene ID & Gene Name & Pathway Name \\
\hline & Secretory & \\
\hline Mm.8655 & Complement component factor $\mathrm{h}$ & Complement and coagulation cascades \\
\hline Mm.235105 & Coagulation factor XIII, A1 subunit & Complement and coagulation cascades \\
\hline Mm.42095 & Secreted frizzled-related protein 4 & Wnt signaling pathway \\
\hline Mm.4339 & Laminin, alpha 5 & Focal adhesion \\
\hline Mm.30211 & Chemokine (C-X-C motif) ligand 14 & Cytokine-cytokine receptor interaction \\
\hline Mm.6813 & Bone morphogenetic protein 4 & TGF-beta signaling pathway \\
\hline Mm.867 & Chemokine (C-C motif) ligand 12 & Cytokine-cytokine receptor interaction \\
\hline $\mathrm{Mm} .8846$ & Fibroblast growth factor 9 & MAPK signaling pathway \\
\hline Mm.18213 & Transforming growth factor, beta 2 & $\begin{array}{l}\text { TGF-beta signaling pathway } \\
\text { Cytokine-cytokine receptor interaction } \\
\text { MAPK signaling pathway }\end{array}$ \\
\hline Mm.1293 & Tumor necrosis factor & $\begin{array}{l}\text { TGF-beta signaling pathway } \\
\text { Cytokine-cytokine receptor interaction } \\
\text { MAPK signaling pathway }\end{array}$ \\
\hline Mm.303231 & Chemokine (C-X-C motif) ligand 12 & Cytokine-cytokine receptor interaction \\
\hline Mm.303231 & Chemokine (C-X-C motif) ligand 12 & Cytokine-cytokine receptor interaction \\
\hline Mm.244263 & Chemokine (C-C motif) ligand 4 & Cytokine-cytokine receptor interaction \\
\hline Mm.1259 & Nerve growth factor & MAPK signaling pathway; \\
\hline Mm.3986 & Growth hormone receptor & $\begin{array}{l}\text { Jak-STAT signaling pathway } \\
\text { Cytokine-cytokine receptor interaction }\end{array}$ \\
\hline Mm.2423 & Collagen, type II, alpha 1 & Focal adhesion \\
\hline Mm.193099 & Fibronectin 1 & Focal adhesion \\
\hline \multirow[t]{2}{*}{ Mm.103593 } & Dickkopf homolog 2 (Xenopus laevis) & Wnt signaling pathway \\
\hline & Extracellular & \\
\hline Mm.4339 & Laminin, alpha 5 & Cell Communication \\
\hline Mm.30211 & Chemokine (C-X-C motif) ligand 14 & Cytokine-cytokine receptor interaction \\
\hline Mm.6813 & Bone morphogenetic protein 4 & TGF-beta signaling pathway \\
\hline Mm.867 & Chemokine (C-C motif) ligand 12 & Cytokine-cytokine receptor interaction \\
\hline $\mathrm{Mm} .8846$ & Fibroblast growth factor 9 & MAPK signaling pathway \\
\hline Mm.18213 & Transforming growth factor, beta 2 & $\begin{array}{l}\text { TGF-beta signaling pathway; } \\
\text { Cytokine-cytokine receptor interaction; } \\
\text { MAPK signaling pathway }\end{array}$ \\
\hline Mm.1293 & Tumor necrosis factor & $\begin{array}{l}\text { TGF-beta signaling pathway; } \\
\text { Cytokine-cytokine receptor interaction; } \\
\text { MAPK signaling pathway }\end{array}$ \\
\hline Mm.303231 & Chemokine (C-X-C motif) ligand 12 & Cytokine-cytokine receptor interaction \\
\hline Mm.155586 & Collagen, type IV, alpha 6 & Cell Communication \\
\hline Mm.244263 & Chemokine (C-C motif) ligand 4 & Cytokine-cytokine receptor interaction \\
\hline Mm.1259 & Nerve growth factor & MAPK signaling pathway \\
\hline Mm.3986 & Growth hormone receptor & Cytokine-cytokine receptor interaction \\
\hline Mm.2423 & Collagen, type II, alpha 1 & Cell Communication \\
\hline \multirow[t]{2}{*}{ Mm.193099 } & Fibronectin 1 & Cell Communication \\
\hline & Plasma Membrane & \\
\hline Mm.6712 & Desmin & Cell Communication \\
\hline Mm.227 & Integrin alpha $\mathrm{V}$ & Focal adhesion \\
\hline Mm.28095 & Filamin, beta & Focal adhesion \\
\hline Mm.193099 & Fibronectin 1 & $\begin{array}{l}\text { Focal adhesion } \\
\text { Cell Communication }\end{array}$ \\
\hline Mm.390683 & Gap junction protein, beta 2 & Cell Communication \\
\hline
\end{tabular}

of hES cells (Dravid et al. 2005). Various researchers identified different molecules e.g. FGF 2 signaling, ECM proteins (Kueh et al. 2006), Noggin and FGF 2 (Xu et al. 2005) to be the key factors in promoting self- renewal of hES cells in vitro. Recently, FGF- 2 was demonstrated to act on MEF to release supportive factors including key members of the TGF $\beta$ pathway viz. inhibin alpha, TGF $\beta 1$, GREM-1, and BMP-4 and reduce differentiation-inducing activity (Greber etal. 2007). Interestingly, our results demonstrate an up regulation of key members of the TGF $\beta$ pathway even in the absence of FGF 2 in the supportive feeder transcriptome.
TGF $\beta$ has been implicated by several groups, in regulating the biology of embryonic stem cells and may help define the selection of cell fate and the progression of differentiation along a lineage (Mishra et al. 2005). We propose that when the hES cells are in close contact with the feeder layers, TGF $\beta$ facilitates proliferation and it is the microenvironment of ES cells that triggers TGF $\beta$ to exert contradictory roles of either facilitating proliferation of ES cells in presence of feeders or inducing differentiation when feeder support is withdrawn. Thus TGF $\beta$ acts through different pathways depending on the presence or absence of feeder support and appears to play dual role in both supporting differentiation and proliferation of hES cells. This hypothesis is further supported by an elegant study carried out by James and coworkers (2005) where they reported that in the undifferentiated hES cells, TGF $\beta$ /activin/nodal pathway is activated through the signal transducer SMAD2/3 and upon early differentiation SMAD1/ 5 signaling gets activated.

Embryonic stem cells share several characteristics of cancer cells including loss of contact inhibition and immortality (Gammill and Bronner, 2002). It is interesting to draw an analogy between cancer cells and surrounding stromal fibroblasts with embryonic stem cells and surrounding feeder fibroblasts. The complex and apparently contradictory role of TGF $\beta$ in cancer biology has been extensively studied where it shifts its role from an inhibitor to a promoter of proliferation during tumor progression (Ao et al. 2007; Elliott et al. 2005). TGF $\beta$ is understood to play a role in the communication between the cancer cells and the surrounding stromal cells. It regulates the interaction between cell and extracellular matrix through induction of extracellular matrix proteins such as fibronectin, collagen, and laminin etc. Several such ECM components were observed to be highly expressed in the supportive feeders (Table 2). The tissue stroma is understood to play an important role during cancer cell proliferation and invasion. The production of growth factors, chemokines and extracellular matrix by the surrounding stromal cells facilitate the malignant progression of cancer and represent an important target for cancer therapies (Wever et al. 2003; Kalluri et al. 2006, Billottet et al. 2008). It is widely accepted that the development of carcinoma is not only due to somatic mutations in epithelial cells but also is influenced by the tumor microenvironment including the stromal fibroblasts (Stover et al. 2007). Similarly for self- renewal of hES cells, feeder fibroblast layers are essential and when the feeder fibroblast support is withdrawn, results in differentiation of hES cells.

Stromal changes at the invasion front in a tumor (Vaughan et al., 2000; Rice et al., 2003) or during wound healing (Tomasek et al. 2002) include the appearance of myofibroblast cells, which are unique cells, an intermediate state between fibroblasts and smooth muscle cells (Gabbiani et al. 1971) that arise from transient differentiation of resident fibroblasts through multiple paracrine mediated pathways including TGF $\beta$ (Shi-wen et al., 2009). They are known to undergo mesenchymal-epithelial interactions and through the secretion of cytokines, chemokines, growth factors and extracellular matrix proteins, they facilitate cell growth and proliferation. To study similar phenomenon occurring in feeder layers, we examined the expression of myofibroblasts specific markers between the transcriptome of supportive and non- supportive feeders. Myosin heavy chain protein, vimentin and desmin were found to be 8,2 and 21 fold up- regulated respectively. 


\section{N. Kumar et al.}

Further assessment of morphological features and presence of $\alpha$ SMA indicates that supportive feeder fibroblasts transiently differentiate into myofibroblasts and this decides whether a feeder layer is supportive or not for ES cells proliferation since the $18.5 \mathrm{dpc}$ MEF comprised predominantly of quiescent fibroblasts. Few polyhedral fibroblasts were also observed in $18.5 \mathrm{dpc}$ MEF

\section{TABLE 4}

\section{COMPARISON OF PUBLISHED PROTEOME DATA WITH TRANSCRIPTOME DATA OF SUPPORTIVE \& NON-SUPPORTIVE FEEDER FIBROBLASTS}

\begin{tabular}{|c|c|c|}
\hline $\begin{array}{l}\text { Proteins detected in the conditioned } \\
\text { medium of supportive feeder fibroblasts } \\
\text { taken from published literature }\end{array}$ & $\begin{array}{c}\text { Fold change of hybridization } \\
\text { intensity between } 13.5 \text { vs } \\
18.5 \text { dpc MEF }\end{array}$ & $\begin{array}{c}\text { Hybridization } \\
\text { intensity in } \\
\text { HFF }\end{array}$ \\
\hline \multicolumn{3}{|l|}{ Extra cellular Matrix \& Remodeling Category } \\
\hline Bone proteoglycan I(Biglycan) & & \pm \\
\hline Bone proteoglycan II (Decorin) & 2.56 & ++++ \\
\hline Cathepsin K (pycnodysostosis) & 3.42 & +++ \\
\hline Collagen $\alpha 1(\mathrm{I})$ & 1.05 & 0 \\
\hline Collagen alpha 1 (III) & 2.56 & ++ \\
\hline Collagen $\alpha-1(v)$ & 1.03 & +++ \\
\hline Collagen alpha $1(\mathrm{VI})$ & 0.30 & \pm \\
\hline Collagen alpha 1 (VIII) & 1.00 & ++ \\
\hline Collagen alpha 1 (XII) & - & +++ \\
\hline Collagen alpha 1 (XIV) & - & - \\
\hline Collagen alpha II (I) & 0.99 & ++++ \\
\hline Collagen alpha II (V) & 2.05 & ++++ \\
\hline Collagen alpha II (VI) & 2.35 & +++ \\
\hline Collagen alpha III (VI) & - & - \\
\hline Hyaluronan and proteoglycan link protein 1 & - & - \\
\hline Hyaluronan synthase 2 & 9.41 & - \\
\hline Hephaestin & 6.2 & \pm \\
\hline Heparin sulfate proteoglycan 2 & - & - \\
\hline Sulfatase 1 & 6.2 & \pm \\
\hline EGF containing fibulin like ECM protein - 1 & 14.8 & ++++ \\
\hline EMILIN-1 & 3.02 & ++++ \\
\hline Fibronectin 1 & 2.74 & ++++ \\
\hline Fibulin-1 & 2.23 & ++++ \\
\hline Fibulin-2 & - & +++ \\
\hline Fibulin-5 & 1.41 & +++ \\
\hline Heparan sulfate Proteoglycan Core Protein & 6.18 & ++ \\
\hline $\begin{array}{l}\text { Inhibin beta } A \text { (activin A, activin AB alpha } \\
\text { peptide) }\end{array}$ & 4.49 & ++++ \\
\hline Laminin gamma -1 chain & 4.67 & +++ \\
\hline Laminin $\alpha-4$ & 2.87 & ++++ \\
\hline Laminin $\beta-1$ & - & ++++ \\
\hline Lumican & - & +++ \\
\hline Lysyl Oxidase-like-1 & 2.92 & ++++ \\
\hline Matrix Metalloproteinase-2 & 2.72 & ++ \\
\hline Metallo proteinase inhibitor-1 (TIMP-1) & 5.49 & ++++ \\
\hline Metallo proteinase inhibitor-2(TIMP-2) & - & ++++ \\
\hline Mimecan & - & - \\
\hline Nidogen & - & - \\
\hline Nidogen I & 6.90 & \pm \\
\hline Nidogen II & 6.93 & +++ \\
\hline Osteoblast Specific Factor 2 (Periostin) & 1.56 & - \\
\hline Plasminogen Activator inhibitor- 1 & 6.01 & +++ \\
\hline Procollagen C-Endopeptidase Enhancer & 1.28 & ++++ \\
\hline Protein-Lysine 6-oxidase & 5.94 & ++++ \\
\hline SPARC & 2.13 & ++++ \\
\hline Spondin 2 & 18.7 & - \\
\hline Stromelysin 1 & 8.62 & ++++ \\
\hline
\end{tabular}

corresponding to proto- myofibroblasts may be because of being cultured in vitro (Tomasek et al. 2002). We believe that similar to facilitating cancer cells proliferation, these cells also facilitate undifferentiated proliferation of ES cells. Thus it is proposed that a complex autocrine / paracrine network exists between feeder cells and ES cells involving the transient differentiation of myofibroblasts in the supportive feeders that upregulate ECM proteins and growth factors including TGF $\beta$ in the supportive feeder layers. Recently mechanical strain of myofibroblast was

\section{TABLE 4 (CONTINUED)}

\begin{tabular}{|c|c|c|}
\hline $\begin{array}{l}\text { Proteins detected in the conditioned } \\
\text { medium of supportive feeder fibroblasts } \\
\text { taken from published literature }\end{array}$ & $\begin{array}{c}\text { Fold change of hybridization } \\
\text { intensity between } 13.5 \text { vs } \\
18.5 \text { dpc MEF } \\
\end{array}$ & $\begin{array}{c}\text { Hybridization } \\
\text { intensity in } \\
\text { HFF }\end{array}$ \\
\hline Tenascin C (Hexabrachion) & - & - \\
\hline TGF- $\beta$ induced protein IG-H3 & - & - \\
\hline Thrombospondin-1 & 5.60 & +++ \\
\hline Versican core protein & - & - \\
\hline \multicolumn{3}{|c|}{ Role in formation \& regulation of cytoskeleton } \\
\hline Actin beta & 2.18 & +++ \\
\hline Actin binding LIM protein 1 & - & +++ \\
\hline Filamin A & - & +++ \\
\hline Gelsolin & 1.58 & ++++ \\
\hline Lamin A/C & - & +++ \\
\hline Laminin alpha 5 & 25.2 & + \\
\hline $\begin{array}{l}\text { Myosin Heavy Chain Peptide } 9(\mathrm{H}) \\
\text { Myosin Heavy Chain Peptide } 10 \text { (M) }\end{array}$ & 5.96 & ++++ \\
\hline Myosin Light Chain & - & - \\
\hline Profilin 2 & 9.62 & - \\
\hline Profilin 1 & 2.62 & ++++ \\
\hline Transgelin 2 & - & - \\
\hline Tubulin beta 1 & - & - \\
\hline Vimentin & 1.9 & ++++ \\
\hline Viniculin & - & - \\
\hline \multicolumn{3}{|l|}{ Growth Factors } \\
\hline Activin A (Inhibin) & - & +++ \\
\hline BMP 1 & 2.91 & \pm \\
\hline BMP 4 & 18.1 & \pm \\
\hline Actinin, alpha 4 & - & - \\
\hline Dickkopf homolog-3 & 5.25 & +++ \\
\hline FGF 2 & - & ++ \\
\hline Follistatin Related Protein-1 (FRP 1) & - & - \\
\hline Gremlin-1 & 1.8 & ++++ \\
\hline IGFBP 1 & - & - \\
\hline IGFBP 2 & 8.35 & ++++ \\
\hline IGFBP 3 & 2.1 & - \\
\hline IGFBP 4 & 3.48 & ++++ \\
\hline IGFBP 5 & - & +++ \\
\hline IGFBP 6 & 3.59 & +++ \\
\hline IGFBP 7 & 2.00 & ++++ \\
\hline Insulin like growth factor 1 & 4.97 & - \\
\hline Insulin like growth factor 2 & 2.07 & +++ \\
\hline $\begin{array}{l}\text { Latent Transforming Growth Factor- } \beta \\
\text { Binding Protein isoform } 1 \text { (LTBP-1) }\end{array}$ & 8.26 & +++ \\
\hline LTBP 3 & 5.06 & - \\
\hline Pigment Epithelium derived factor & - & ++++ \\
\hline STAT 3 & 4.7 & \pm \\
\hline TGF alpha & - & - \\
\hline TGF beta 1 & 2.9 & + \\
\hline TGF beta 1 induced transcript 4 & 6.28 & - \\
\hline Vasorin & - & - \\
\hline ADAM 11 & & - \\
\hline
\end{tabular}

Id change of hybridization Hybridization feeder fibroblast taken from published literature

TGF- $\beta$ induced protein IG-H3

Actin beta

Actin binding LIM protein 1

Laminin alpha 5

Myosin Light Chain

Tubulin beta

BMP

BMP

FGF 2

Gremlin-1

IGFBP 3

IGFBP 4

Insulin like growth factor 1

Latent Transforming Growth Factor- $\beta$

Binding Protein isoform 1 (LTBP-1)

STAT 3

TGF alpha

ADAM 11

\section{.}

.

.


reported to induce autocrine or paracrine signaling through TGF $\beta$ super- family ligands that supports hES cells self- renewal (Saha etal.2008). Further studies are ongoing in this direction to explore the phenomenon still better.

\section{Materials and Methods}

\section{Cell culture}

\section{Human fetal fibroblast (HFF) culture}

Human fetal fibroblast culture, with prior permission from Institute Ethics Committee, was established as described earlier (Kumar et al., 2009).

\section{Mouse embryonic fibroblast (MEF) culture}

13.5 and $18.5 \mathrm{dpc}$ CF-1 mouse embryos were washed three times with phosphate buffer saline (PBS) containing $1 \% \mathrm{v} / \mathrm{v}$ penicillin-streptomycin. Using sterile scissors limbs, head, tail and dark red organs were removed. Remaining body parts were finely minced in $0.5 \%$ Trypsin EDTA (Sigma, St Louis, MO) and incubated at $37^{\circ} \mathrm{C}$ for $20 \mathrm{~min}$. Tissues were then mixed with equal volume of fetal bovine serum (HyClone, South Logan, UT) to stop the activity of Trypsin EDTA. Cells were released by triturating gently and centrifuged at $1000 \mathrm{rpm}$ for $5 \mathrm{~min}$. Pellets were then resuspended in to media containing DMEM high glucose (Gibco/ Invitrogen, Carlsbad, CA), $10 \%$ FBS, $1 \%$ v/v L-Glutamine (Gibco), $1 \%$ v/v non essential amino acids (Sigma) and $1 \% \mathrm{v} / \mathrm{v}$ Pen/strep (Sigma) and incubated in T-75 flasks (Nunc, Rochestor, NY) at $37^{\circ} \mathrm{C} \& 5 \% \mathrm{CO}_{2}$. Cells were monitored for their growth and sub-cultured regularly. For passaging, confluent cultures were washed with PBS and then incubated with $0.05 \%$ Trypsin EDTA for 4-5 min. The pellet was re-suspended in to MEF media and incubated at $37^{\circ} \mathrm{C} \& 5 \% \mathrm{CO}_{2}$. Cells grown up to passage 3 from 8- 10 flasks were pooled together and used for further studies.

\section{Microarray analysis}

Transcriptional changes between 13.5 and $18.5 \mathrm{dpc}$ MEF were studied using Agilent Mouse Genome 8x15k array (AMADID 16270) starting with total RNA. Human fetal fibroblasts were similarly analyzed using human genome $8 \times 15 \mathrm{k}$ array (AMADID 16332). All the three arrays were done using single color microarray based gene expression analysis.

\section{RNA extraction and quality control}

For RNA extraction, cells were suspended in RNAlater (Qiagen, USA)) immediately after harvesting at room temperature. After permeabilisation of RNAlater for at least an hour, total RNA was isolated from the cells using RNAeasy Mini kit (Qiagen, USA) according to the instructions of the manufacturer. RNA integrity was assessed using RNA 6000 Nano Lab Chip on the 2100 Bioanalyzer (Agilent, USA) following the manufacturer's protocol. Total RNA purity was assessed by the NanoDrop Spectrophotometer (Nanodrop Technologies, USA). Total RNA with OD260/ OD280>1.8 and OD260/OD270 $\geq 1.3$ was used for microarray experiments.

\section{CRNA synthesis, labeling and microarray hybridization}

Low RNA Input Fluorescent Linear Amplification Kit (Agilent, CA) was used for labeling. Briefly, both first and second strand cDNA were synthesized by incubating 500ng of total RNA with $1.2 \mu \mathrm{l}$ of oligo dT-T7 Promoter Primer in nuclease-free water at $65^{\circ} \mathrm{C}$ for $10 \mathrm{~min}$ followed by incubation with $4.0 \mu \mathrm{l}$ of $5 \diamond$ First strand buffer, $2 \mu \mathrm{l}$ of $0.1 \mathrm{M} \mathrm{DTT}, 1 \mu \mathrm{l}$ of $10 \mathrm{mM}$ dNTP mix, $1 \mu \mathrm{l}$ of $200 \mathrm{U} / \mu \mathrm{l}$ MMLV-RT, and $0.5 \mu \mathrm{l}$ of $40 \mathrm{U} / \mu \mathrm{l}$ RNaseOUT, at $40^{\circ} \mathrm{C}$ for 2 hour. Immediately following cDNA synthesis, the reaction mixture was incubated with $2.4 \mu \mathrm{l}$ of $10 \mathrm{mM}$ Cyanine-3-CTP (Perkin-Elmer, MA), $20 \mu$ l of $4 \mathrm{X}$ Transcription buffer, $8 \mu \mathrm{l}$ of NTP mixture, $6 \mu \mathrm{l}$ of $0.1 \mathrm{M}$ DTT, $0.5 \mu \mathrm{l}$ of RNaseOUT, $0.6 \mu \mathrm{l}$ of Inorganic pyrophosphatase, $0.8 \mu \mathrm{l}$ of T7 RNA polymerase, and $15.3 \mu \mathrm{l}$ of nuclease-free water at $40^{\circ} \mathrm{C}$ for 2 hour. Qiagen's RNeasy mini spin columns were used for purifying amplified samples. The quantity and specific activity of cRNA was determined by using NanoDrop spectrophotometer. Samples with specific activity $>8$ were used for hybridization. $825 \mathrm{ng}$ of each Cyanine 3 labeled CRNA in a volume of $41.8 \mu$ l were combined with $11 \mu$ l of $10 x$ blocking agent and $2.2 \mu \mathrm{l}$ of $25 \mathrm{x}$ fragmentation buffer, and incubated at $60^{\circ} \mathrm{Cfor} 30$ minutes in dark. The fragmented cRNA were mixed with $55 \mu$ of $2 x$ hybridization buffer. About $10 \mu \mathrm{l}$ of the resulting mixture was applied to the $8 \times 15 \mathrm{k}$ Gene Expression Microarray (Agilent Technologies), and hybridized at $65^{\circ} \mathrm{C}$ for 17 hours. After hybridization, slides were washed with wash buffer for $1 \mathrm{~min}$ at room temperature followed by a $1 \mathrm{~min}$ wash with wash buffer II at $37^{\circ} \mathrm{C}$. Slides were finally rinsed with acetonitrile for cleaning up and drying.

\section{Scanning \& feature extraction}

Hybridized arrays were scanned at $5 \mu \mathrm{m}$ resolution on a DNA scanner and data extraction from images was done using Feature Extraction software.

\section{Data analysis and biological interpretation}

Microarray output images were manually examined for excessive noise and physical anomalies. Feature extracted data was analyzed using GeneSpring GX version 7.3.1 (Genotypic, Bangalore, India) and Microsoft Excel software. Normalization of the data was done within GeneSpring using the recommended per chip and per gene data transformation which included the set measurement less than 0.01 to 0.01 , per chip normalization to 50th percentile and normalization of each gene to the median. Further quality control of normalized data was done using correlation based condition tree to eliminate bad experiments. In order to assess the differentially expressed genes between 13.5 and $18.5 \mathrm{dpc}$ MEF, up and down regulated genes were subjected to functional analysis using GeneSpring GX software ontology browser by selecting appropriate parameters in the tool. The statistically significant transcripts were annotated using web based Biointerpreter version 1.1 (Genotypic) software to generate clusters of functionally related genes to understand their biological significance.

Comparative studies of microarray data with published proteomics data

A total of eighty-five proteins reported earlier in the conditioned medium of supportive feeder layers (Lim et al. 2002; Prowse et al. 2005 , 2007; Kueh et al. 2006; Eiselleova et al. 2008) and belonging to the categories of extracellular matrix proteins, cell cytoskeleton and growth factors, were analyzed at the transcriptome level between supportive (13.5dpc MEF and HFF) and non- supportive (18.5dpc MEF) feeders.

\section{Scanning electron microscopy}

Fibroblast cells were grown on sterile $100 \mathrm{~mm}^{2}$ glass coverslips. They were fixed in $2.5 \%$ glutaraldehyde (Pelco International, Redding, CA) in $0.1 \mathrm{M}$ cacodylate (Pelco) buffer ( $\mathrm{pH} 7.4$ ), after two washes in phosphate buffer saline (PBS) to remove media and serum contents. After several washes in the cacodylate buffer, the cells were post fixed with buffered $1.0 \%$ osmium tetroxide (Pelco) for $30 \mathrm{~min}$ at $4^{\circ} \mathrm{C}$. Later the coverslips were washed in buffer, dehydrated in a ascending series of ethanol and critical point dried for $20 \mathrm{~min}$ in liquid $\mathrm{CO}_{2}$ in a $\mathrm{E} 3100$ critical point drier (Quorum technologies; www.quorumtech.com, UK). The coverslips were then stuck to aluminum stubs and coated with gold-palladium for $20 \mathrm{sec}$ at 20 mA using Polaron sputter coater (SC7640, Quorum Technologies) coating apparatus. Fibroblasts were then examined under JEOL 6400 scanning electron microscope (JEOL, Tokyo, Japan) and representative areas were photographed.

\section{Immunocytochemical localization of $\alpha$-smooth muscle actin ( $\alpha-$ SMA)}

Adherent fibroblast cells on coverslips were fixed with $4 \%$ paraformaldehyde in PBS (Sigma) for 10 min and permeablized with $0.1 \%$ Triton$X 100$ for 5 min. Cells were washed, blocked with 3\% BSA (Sigma) and 
later incubated overnight with monoclonal $\alpha$ SMA antibody (Dako, Glostrup, Denmark) at $4^{\circ} \mathrm{C}$. AlexaflourTM 488 (Molecular Probe, Invitrogen) conjugated secondary antibody diluted 1: 1000 in blocking solution was used to visualize the specific localization of $\alpha$ SMA antibody in supportive and nonsupportive fibroblasts. Representative areas were photographed under florescent microscope (90i, Nikon, Japan).

\section{Western Blot analysis}

Feeder fibroblasts of $13.5 \mathrm{dpc}$ MEF, $18.5 \mathrm{dpc}$ MEF and HFF, cultured in T-75 flasks were harvested into 500 ul of $1 \mathrm{X}$ lysis solution (10mM Tris, $\mathrm{pH} 7.6,100 \mathrm{mM}$ Nacl, $1 \mathrm{mM}$ EDTA, $1 \% \mathrm{v} / \mathrm{v}$ Triton X 100, 10\% v/v Glycerol) supplemented with $1 \% \mathrm{v} / \mathrm{v}, 1 \mathrm{X}$ protease inhibitor mix (Amersham, GE Healthcare). 20ug of protein lysate was electrophoresed on $12 \%$ SDSPAGE gel followed by electroblotting on PVDF membrane (Amersham, GE Healthcare). Membrane was then blocked with 5\% NFDM in TBST and incubated with monoclonal primary mouse anti $\alpha$-SMA antibody (1:1500) (Chemicon International, CA, USA) at $4^{\circ} \mathrm{C}$ over night. Detection of $\alpha$-SMA was performed by incubating membrane with HRP conjugated goat anti mouse secondary antibody $(1: 10,000)$ (Jackson Immuno Research Laboratories) for 2 hrs at room temperature followed by chemiluminescent (SuperSignal West Pico, Pierce, USA) exposure of Hyperfilm ${ }^{\mathrm{TM}}$ ECL (Amersham, GE Healthcare). Monoclonal mouse anti GAPDH antibody (1:5000) (Calbiochem, USA) was used as house keeping to quantitate alpha SMA Expression in various fibroblasts using Gene Tools software (Syngene, UK).

\section{Acknowledgements}

This study (BTPR3985/MED/14/49712003) was financially supported by Department of Biotechnology, Govt. of India. Authors are grateful to Prof Jayesh Bellare, Sillicate Lab, Indian Institute of Technology, Mumbai, for assisting in Scanning Electron Microscopy studies.

\section{References}

BILLOTTET, and JOUANNEAU, J. (2008). Tumor-stroma interactions. Bull Cancer 95: 51-56.

DE WEVER, O. and MAREEL, M. (2003). Role of tissue stroma in cancer cell invasion. J Patho/200: 429-447.

DIECKE, S., QUIROGA-NEGREIRA, A., REDMER, T. AND BESSER, D. (2008) FGF2 signaling in mouse embryonic fibroblasts is crucial for self-renewal of embryonic stem cells. Cells Tissues Organs 188: 52-61.

DRAVID, G., YE, Z., HAMMOD, H., CHEN, G., PYLE, A., DONOVAN, P., YU, X. and CHENG, L. (2005). Defining the role of Wnt/ $\beta$-catenin signaling in the survival, proliferation, and self renewal of human embryonic stem cells. Stem Cells 23: 1489-1501.

EISELLEOVA, L., PETERKOVA, I., NERADIL, J., SLANINOVA, I., HAMPL, A. and DVORAK, P. (2008). Comparative study of mouse and human feeder cells for human embryonic stem cells. Int J Dev Bio/52: 353-363

ELLIOTT, R.L. and BLOBE, G.C. (2005). Role of transforming growth factor beta in human cancer. J Clin Onco/23: 2078-2093.

GABBIANI, G., RYAN, G. and MAJNE, G. (1971). Presence of modified fibroblast in granulation tissue and their possible role in wound contraction. Experimentia 27: $549-550$

GAMMILL, L.S., and BRONNER-FRASER, M. (2002). Genomic analysis of neural crest induction. Development 129: 5731-5741.

GREBER, B., LEHRACH, H. and ADJAYE, J. (2007). Fibroblast growth factor 2 modulates transforming growth factor b signaling in mouse embryonic fibroblasts and human ESCs (hESCs) to support hESC self renewal. Stem Cells 25: 455-464.

JAMES, D., LEVINE, A.J., BESSER, D. and HEMMATI-BRIVANLOU, A. (2005).
TGF $\beta /$ activin/nodal signaling is necessary for the maintenance of pluripotency in human embryonic stem cells. Development 132: 1273-1282.

KALLURI, R. and ZEISBERG, M. (2006). Fibroblasts in cancer. Nat Rev Cancer5: 392-401.

KUEH, J., RICHARDS, M., SZE-WAI, N.G., CHAN, W.K. and BONGSO, A. (2006). The search for factors in human feeders that support the derivation and propagation of human embryonic stem cells: preliminary studies using transcriptome profiling by serial analysis of gene expression. Fertil Steril 85 1843-1846.

KUMAR, N., HINDUJA, I., NAGVENKAR, P., PILLAI, L., ZAVERI, K., MUKADAM, L., TELANG, J., DESAI, S., MANGOLI, V., MANGOLI, R., PADGAONKAR, S., KAUR, G., PURI, C. and BHARTIYA, D. (2009). Derivation and characterization of two genetically unique human embryonic stem cell lines on in-house derived human feeders. Stem Cells Dev 18:435-445.

LIM, J.W.E. and BODNAR, A. (2002). Protemome analysis of conditioned medium form mouse embryonic fibroblast feeder layers which support the growth of human embryonic stem cells. Proteomics 2: 1187-1203.

M, A.O., FRANCO, O.E., PARK, D., RAMAN, D., WILLIAMS and HAYWARD, S.W (2007). Cross-talk between paracrine-acting cytokine and chemokine pathways promotes malignancy in benign human prostatic epithelium. Cancer Res 67: 4244-4253.

MARTIN, M.J., MUOTRI, A., GAGE, F. and VARKI, A. (2005). Human embryonic stem cells express an immunogenic nonhuman sialic acid. Nat Med 11: 228232.

MISHRA, L., DERYNCK, R. and MISHRA, B. (2005). Transforming growth factor$\beta$ signaling in stem cells and cancer. Cell Signaling 310: 68-71.

PROWSE, A.B., MC QUADE, L.R., BRYANT, K.J., DYK, D.D., TUCH, B.E. and GRAY, P.P. (2005). A proteome analysis of conditioned medium from mouse embryonic fibroblast feeder layers which support the growth of human embryonic stem cells. Proteomics 5: 978-989.

PROWSE, A.B., MC QUADE, L.R., BRYANT, K.J., MARCAL, H. and GRAY, P (2007). Identification of potential pluripotency determinants for human embryonic stem cells following proteomic analysis of human and mouse fibroblas conditioned media. J Proteome Res 6: 3796-3807.

RICE, N.A. and LEINWAND, L.A. (2003). Skeletal myosin heavy chain function in cultured lung myofibroblasts. J Cel/ Bio/163: 119-129.

RICHARDS, M., TAN, S., FONG, C.Y., BISWAS, A., CHAN, W.K. and BONGSO, A (2003). Comparative evaluation of various human feeders for prolonged undifferentiated growth of human embryonic stem cells. Stem Cells 21: 546-556.

ROBERTS, A. and MISHRA, L. (2005). Role of TGF- $\beta$ in cells and cancer Oncogene 24: 5667

SAHA, S., JI, L., DE PABLO, J.J. and PALECEK, S.P. (2008). TGF beta/Activin/ Nodal pathway in inhibition of human embryonic stem cell differentiation by mechanical strain. Biophys J94: 4123-4133.

SHI-WEN, X., PARAPURAM, S.K., PALA, D., CHEN, Y., CARTER, D.E. EASTWOOD, M., DENTON, C.P., ABRAHAM, D.J. and LEASK, A. (2009) Requirement of transforming growth factor beta-activated kinase 1 for trans forming growth factor beta-induced alpha-smooth muscle actin expression and extracellular matrix contraction in fibroblasts. Arthritis Rheum 60: 234-241.

STOVER, D.G., BIERIE, B. and MOSES, H.L. (2007). A delicate balance: TGF-b and the tumor microenvironment. J Cel/ Biochem 101: 851-861.

TOMASEK, J.J., GABBIANI, G., HINZ, B., CHAPONNIER, C. and BROWN, R.A (2002). Myofibroblasts and mechanoregulation of connective tissue remodeling. Nat Rev Mol Cel/ Bio/3: 349-363.

VAUGHAN, M.B., HOWARD, E.W. and TOMASEK, J.J. (2000). Transforming growth factor-beta1 promotes the morphological and functional differentiation of the myofibroblast. Exp Cell Res 257: 180-189.

XU, R.H., PECK, R.M., LI, D., FENG, X., LUDWIG, T. and THOMSON, J.A. (2005) Basic FGF and suppression of BMP signaling sustain undifferentiated proliferation of human ES cells. Nat Methods 2: 185-190. 


\section{Further Related Reading, published previously in the Int. J. Dev. Biol.}

See Special Issue Pattern Formation edited by Michael K. Richardson and Cheng-Ming Chuong at: http://www.ijdb.ehu.es/web/contents.php?vol=53\&issue=5-6

Comparative study of mouse and human feeder cells for human embryonic stem cells Livia Eiselleova, Iveta Peterkova, Jakub Neradil, Iva Slaninova, Ales Hamp and Petr Dvorak Int. J. Dev. Biol. (2008) 52: 353-363

Common culture conditions for maintenance and cardiomyocyte differentiation of the human embryonic stem cell lines, BG01 and HUES-7

Chris Denning, Cinzia Allegrucci, Helen Priddle, Maria D. Barbadillo- Muñoz, David Anderson, Tim Self, Nigel M. Smith, C. Tony Parkin and Lorraine E. Young

Int. J. Dev. Biol. (2006) 50: 27-37

The stroma reaction myofibroblast: a key player in the control of tumor cell behavior Alexis Desmoulière, Christelle Guyot and Giulio Gabbiani

Int. J. Dev. Biol. (2004) 48: 509-517

Functional analysis of the TGFbeta receptor/Smad pathway through gene ablation in mice M J Goumans and C Mummery

Int. J. Dev. Biol. (2000) 44: 253-265

Type beta transforming growth factors and activins in differentiating embryonal carcinoma cells, embryonic stem cells and early embryonic development

C L Mummery and A J van den Eijnden-van Raaij

Int. J. Dev. Biol. (1993) 37: 169-182
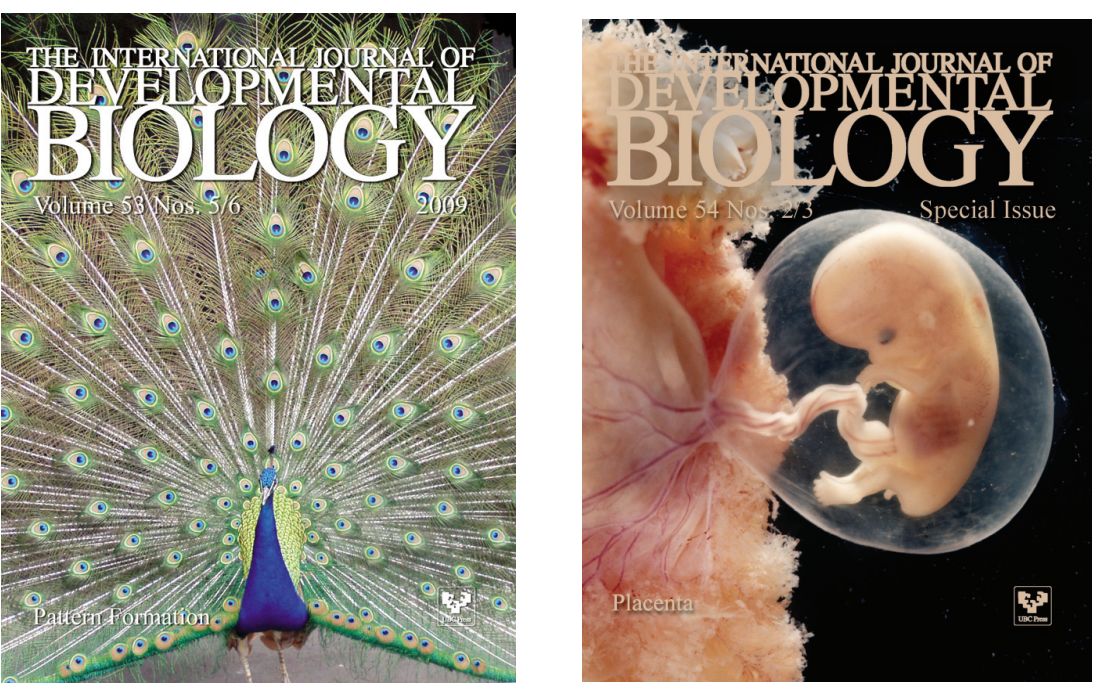

5 yr ISI Impact Factor (2009) = 3.253

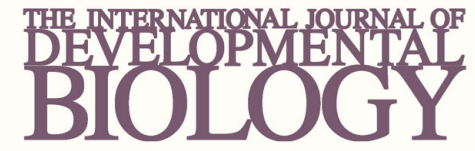

Volume 54 Nos. 6/7 Special Issue

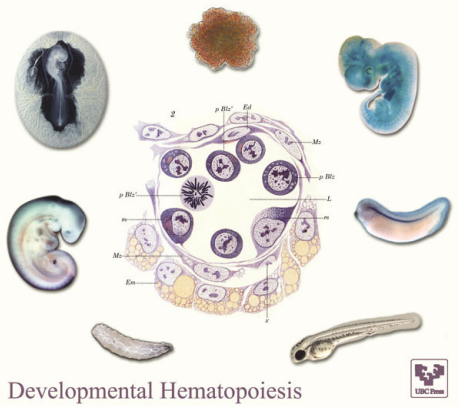

